\title{
EFEKTIVITAS SARINGAN ABU SEKAM PADI UNTUK MENURUNKAN KEKERUHAN PADA AIR SUNGAI MARTAPURA
}

\author{
Syarifudin A., Imam Santoso. \\ Poltekkes Kemenkes Banjarmasin Jurusan Kesehatan Lingkungan \\ Jl. H. Mistar Cokrokusumo No. 1A Banjarbaru Kalimantan Selatan 70714 \\ E-maill: syarif_yazid@yahoo.com
}

\begin{abstract}
The Effectiveness of Rice Husk Ash Filter to Reduce Turbidity of Martapura
River Water. Martapura River water is used by people living on riverbanks for cooking, washing, bathing, and others. The main problem of Martapura river water is the turbidity which is relatively high so it needs to be processed first before use. The preliminary test conducted on August 15, 2016 shows the value of turbidity of Martapura river water at 38.9 NTU. This research was an experimental research with the one group pretest and posttest design which aimed to determine the effectiveness of the filter to reduce the turbidity of Martapura river water. The medium used was rice husk ash with variation of thickness were $13 \mathrm{~cm}, 26 \mathrm{~cm}$, and $39 \mathrm{~cm}$. The effectiveness of filtration was determined by comparing the turbidity of water filtered with standards. The turbidity of Martapura river water before filtered was 35.7 NTU. After filtered by $13 \mathrm{~cm}, 26 \mathrm{~cm}$ and $39 \mathrm{~cm}$ filter, the turbidity of water decreased consecutive to $2.97 \mathrm{NTU}, 1.17 \mathrm{NTU}$, and $0.95 \mathrm{NTU}$, with decreasing percentages respectively of $91.7 \%, 96.7 \%$ and $97.3 \%$. All filtered water showed turbidity fulfilled both the standar of clean water and drinking water so that rice husk ash filter was effective decreased turbidity of Martapura river water. Filtered water is recommended to be cooked first to boil when used for drinking water because the number of bacteria of Coli has not been studied. Further research needs to be conducted by adding other parameters according to water quality standard
\end{abstract}

Keywords: Rice husk Ash; Turbidity; Martapura river water

\begin{abstract}
Abstrak: Efektivitas Saringan Abu Sekam Padi untuk Menurunkan Kekeruhan pada Air Sungai Martapura. Air Sungai Martapura digunakan oleh masyarakat yang tinggal di bantaran sungai untuk memasak, mencuci, mandi, dan lain-lain. Permasalahan utama air sungai Martapura adalah kekeruhan air yang relatif tinggi. Uji pendahuluan menunjukkan nilai kekeruhan air sungai sebesar 38,9 NTU. Penelitian ini merupakan penelitian eksperimental dengan rancangan One Group Pretest and Posttest Design untuk mengetahui efektifitas saringan dalam menurunkan kekeruhan air sungai Martapura. Media yang digunakan abu sekam padi dengan ketebalan $13 \mathrm{~cm}, 26 \mathrm{~cm}$, dan $39 \mathrm{~cm}$. Efektifitas penyaringan ditentukan dengan membandingkan kekeruhan dengan standar yang berlaku. Kekeruhan air sungai sebelum disaring adalah 35,7 NTU. Setelah melewati saringan $13 \mathrm{~cm}, 26 \mathrm{~cm}$ dan $39 \mathrm{~cm}$, kekeruhan berturut-turut turun menjadi 2,97 NTU, 1,17 NTU, dan 0,95 NTU, dengan prosentase penurunan masing-masing 91,7\%, 96,7\% dan $97,3 \%$. Secara statistik, terdapat perbedaan kekeruhan air sungai sebelum dan setelah disaring pada tingkat kepercayaan 95\%. Seluruh hasil saringan menunjukkan kekeruhan di bawah standar air bersih maupun air minum sehingga saringan abu sekam padi dinyatakan efektif menurunakan kekeruhan air sungai. Air hasil saringan dianjurkan untuk dimasak terlebih dulu sampai mendidih.
\end{abstract}

Kata Kunci: Abu sekam padi; kekeruhan; air sungai Martapura 


\section{PENDAHULUAN}

Kebutuhan sehari-hari masyarakat pedesaan di Indonesia umumnya banyak memanfaatkan sumber air yang ada di lingkungan, seperti air sungai, sumur dan rawa. Hal ini mereka lakukan karena keterbatasan sarana penunjang air bersih. Keterbatasan penyediaan air bersih yang memenuhi syarat memacu perlu adanya teknologi tepat guna yang disesuaikan dengan keadaan lingkungan untuk pengelolahan air tersebut ${ }^{[1]}$.

Kehidupan penduduk di Propinsi Kalimantan Selatan sangat dekat dengan sungai. Mereka beraktivitas dan menjadikan sungai sebagai sumber kehidupan. Air sungai Martapura merupakan komponen lingkungan yang penting bagi kehidupan, selain sebagai penyusun tubuh mahluk hidup, juga digunakan masyarakat disekitar bantaran sungai dalam berbagai aktivitas, diantaranya untuk keperluan rumah tangga seperti mandi, cuci, memasak dan keperluan rumah tangga lainnya.

Air merupakan sumber daya yang sangat penting bagi kehidupan manusia, baik untuk dikonsumsi maupun digunakan untuk kepentingan lain, namun, air bersih sangat sedikit persediaannya karena banyak sumber daya air tercemar[2].

Sebagian besar penduduk tinggal di bantaran sungai Martapura membuang limbah rumah tangga ke sungai serta adanya lumpur yang dilewati aliran sungai dari bagian hulu sungai hingga kebagian hilir sungai yang menyebabkan air sungai menjadi sangat keruh.

Masalah yang sering ditemukan pada masyarakat bahwa air sungai yang digunakan cenderung memiliki kekeruhan yang tinggi sehingga perlu dilakukan pengolahan sebelum dapat digunakan. Berdasarkan Uji Pendahuluan yang dilakukan pada tanggal 15 Agustus 2016 nilai kekeruhan air sungai Matrapura sebesar 38,9 NTU.

Penelitian yang dilakukan Seyllina Yuni Olvira (2016) menurunkan angka kekeruhan air Sungai Martapura menggunakan media pasir Taluk, angka kekeruhan awal air Sungai Martapura sebelum dilakukan pengolahan adalah 171 NTU setelah dilakukan pengolahan menjadi 43 NTU dengan metode filtrasi menggunakan pasir Taluk dengan ketebalan pasir $60 \mathrm{~cm}$ dan debit inlet 0,05 $\mathrm{L} / \mathrm{dt}^{[3]}$.

Penurunan tingkat kekeruhan air Sungai Martapura menggunakan pasir Awang Bangkal dengan ketebalan $20 \mathrm{~cm}$ dengan angka kekeruhan rata-rata awal air Sungai Martapura adalah 12,7 NTU dapat menurunkan angka kekeruhan pada air Sungai Martapura menjadi 4,2 NTU[4].

Pada penelitian yang dilakukan Agus Syaifudinnor (2006) menurunkan angka kekeruhan air Sungai Martapura menggunakan media pasir Tambak Anyar, angka kekeruhan awal air Sungai Martapura sebelum dilakukan pengolahan adalah 76 NTU setelah dilakukan pengolahan menjadi 4,0 NTU dengan metode filtrasi menggunakan pasir Tambak Anyar dengan ketebalan pasir 50 $\mathrm{cm}$ dan debit $30 \mathrm{~m}^{3} / \mathrm{Jam} / \mathrm{m}^{2[5]}$.

Pengolahan terhadap air yang akan digunakan sebagai air minum mutlak diperlukan terutama apabila air tersebut berasal dari permukaan[6]. Bahan abu sekam padi yang relatif murah dan dapat dijadikan sebagai bahan penyaring (filtrasi), karena bentuknya yang tidak terlalu tebal, sehingga memungkinkan penyaringan berlangsung secara merata. Abu sekam padi efektif dalam menurunkan nilai kekeruhan yang terdapat pada air sungai. Pada proses penyaringan dengan saringan abu sekam padi, partikel-partikel tersuspensi dengan ukuran yang lebih besar dari pori-pori saringan akan 
tertahan di antara butiran-butiran abu sekam. Saringan abu sekam padi sangat cocok untuk komunitas skala kecil atau skala rumah tangga. Hal ini karena debit air bersih yang dihasilkan relatif kecil. Saringan abu Sekam Padi adalah suatu alat yang dipakai untuk mengolah air sungai menjadi air bersih yang dapat digunakan untuk menurunkan nilai kekeruhan.

\section{BAHAN DAN CARA PENELITIAN}

Penelitian pengolahan air sungai Martapura merupakan penelitian eksperimental. Penelitian ini dilakukan uji coba saringan abu sekam padi dengan variasi tingkat ketebalan saringan. Rancangan penelitian ini dilakukan pengukuran pertama (Pretest) kemudian dikenakan perlakuan dan dilakukan pengukuran kedua (Posttest), sehingga dapat dilihat perubahan-perubahan yang terjadi setelah adanya eksperimen. Data primer dikumpulkan dari hasil pengukuran nilai Kekeruhan air sungai Martapura sebelum dan sesudah penyaringan dengan abu sekam padi dengan variasi ketebalan saringan. Data sekunder dikumpulkan dari studi kepustakaan yang berhubungan dengan penelitian. Data dianalisis secara deskriptif dan analitik menggunakan uji beda rata-rata dengan tingkat kesalahan

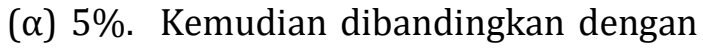
persyaratan dan teori yang berhubungan dengan syarat baku butu air minum sesuai dengan Permenkes 492 tuhun 2010 tentang persyratan kualitas air minum.

\section{HASIL DAN PEMBAHASAN}

Hasil pengukuran debit air sebelum perlakuan sebesar 0,2 liter/detik (12 liter/menit), perlakuan satu pada ketebalan $13 \mathrm{~cm}$ (menggunakan satu filter), sebesar 0.03 liter/detik (1,8 liter/menit), perlakuan dua ketebalan 26 cm (menggunakan dua filter), sebesar 0,01 liter/detik (0,5 liter/menit), sedangkan pada perlakuan tiga (menggunakan tiga filter) ketebalan $39 \mathrm{~cm}$ debit air keluar sebesar $\quad 0,07 \quad$ liter/perdetik $\quad(0,42$ liter/menit). Penyaringan dilakukan secara seri yaitu dengan cara menyaring air sungai pada filter 1 , ditambahkan filter 2 dan terakhir digabung seri dengan fiter 3. Hasil pengukuran nilai kekeruhan, pada masing-masing seri ketebalan saringan abu sekam padi dapat dilihat pada tabel 1 .

Tabel 1. Hasil pengukuran parameter kekeruhan (NTU) pada masing-masing seri ketebalan saringan abu sekam padi pada air sungai Martapura

\begin{tabular}{|c|c|c|c|c|}
\hline \multirow[t]{3}{*}{ Replikasi } & \multirow[t]{3}{*}{ Awal } & \multicolumn{3}{|c|}{$\begin{array}{c}\text { Ketebalan Media Abu Sekam Padi }(\mathrm{cm}) \text { pada filter } \\
\text { digabung seri }\end{array}$} \\
\hline & & 1 Filter (A) & 2 Filter ( B ) & 3 Filter (C) \\
\hline & & 13 & 26 & 39 \\
\hline 1 & 37,2 & 2,9 & 1,21 & 0,93 \\
\hline 2 & 36,3 & 1.92 & 1,18 & 0,95 \\
\hline 3 & 33,6 & 4,08 & 1,13 & 0,98 \\
\hline Rata-rata & 35,7 & 2,97 & 1,17 & 0,95 \\
\hline Effektivitas (\%) & & 91,7 & 96,7 & 97,3 \\
\hline
\end{tabular}

Sumber : Data hasil uji laboratorium PDAM Intan Banjar Tahun 2017

Persyaratan nilai kekeruhan baku mutu air menurut permenkes 416 tahun 1990 untuk air bersih adalah 25 NTU, sedangkan persyaratan untuk air minum menurut permenkes 492 tahun 2010 nilai kekeruhan untuk air minum sebesar 5 NTU. Pada Tabel 4.1. terlihat rata rata penurunan nilai kekeruhan dibandingkan 
sebelum dan setelah dilakukan penyaringan. Sebelum dilakukan penyaringan nilai kekeruhan sebesar 35,7 NTU, pada perlakuan satu (menggunakan satu filter) ketebalan filter $13 \mathrm{~cm}$ sebesar 2,97, perlakuan dua ketebalan filter $26 \mathrm{~cm}$ sebesar 1,17 NTU (menggunakan dua filter), dan perlakuan tiga ketebalan filter $39 \mathrm{~cm}$ (menggunakan tiga filter) sebesar 0,95 NTU telah memenuhi persyaratan kualitas air. Efektivitas penurunan nilai kekeruhan pada perlakuan satu ketebalan $13 \mathrm{~cm}$ sebesar 91,7 \%, perlakuan dua ketebalan $26 \mathrm{~cm}$ sebesar 96,7\%, sedangkan perlakuan tiga pada ketebalan $39 \mathrm{~cm}$ sebesar $97,3 \%$.

Signifikansi perbedaan rata-rata kekeruhan, menurut variasi perlakuan dianalisis menggunakan uji anova satu arah. Untuk melaksanakan uji Anova wajib melaksanakan uji homogenitas. Uji homogenitas digunakan untuk mengetahui apakah data yang dimiliki sudah homogen diperoleh nilai signifikan $(\mathrm{P}=$ $0,130)$ berada di atas $\alpha 5 \%(P=0,05)$ sehingga Ho diterima, dapat dikatakan data tersebut homogen, segingga memenuhi syarat untuk dilakukan uji Anova satu arah.

Untuk menilai perbedaan rata-rata parameter yang diuji yaitu kekeruhan, digunakan uji anova satu arah, menunjukan bahwa nilai signifikan $(\mathrm{P}=$ $0,000)$ lebih kecil dari nilai $\alpha 5 \%(P=0,05)$ sehingga Ho ditolak, artinya ada perbedaan yang signifikan antar kelompok variabel yang diuji. Perlakuan Kontrol terhadap ketebalan perlakuan satu, dua, dan tiga. Untuk melihat signifikansi perbedaan pada masing-masing perlakuan dilakukan uji multiple comparison menggunakan LSD.

Uji LSD atau uji beda nyata terkecil merupakan lanjutan dari analisis varians (anova) yang bertujuan menentukan perbedaan secara statistik nilai parameter kekeruhan, berdasarkan variabel pengaruh (ketebalan filter). Misalnya antara $0 \mathrm{~cm}$ dengan $13 \mathrm{~cm}, 13 \mathrm{~cm}$ dengan $26 \mathrm{~cm}$ dan seterusnya hingga $26 \mathrm{~cm}$ dengan $39 \mathrm{~cm}$. Perbedaan hasil perlakuan tersebut ditentukan dari signifikansi dua parameter yang dibandingkan tersebut. Jika nilai signifikansi $<\alpha(5 \%)$ maka hasil perlakuan dinyatakan berbeda satu sama lain. (dalam tabel biasanya diberikan tanda bintang $\left({ }^{*}\right)$ pada kolom beda ratarata (mean difference). Sebaliknya jika nilai signifikansi $>\alpha(5 \%)$ maka hasil perlakuan dinyatakan tidak berbeda secara statistik. Dari perhitungan diperoleh perlakuan kontrol ada perbedaan yang signifikan terhadap ketebalan perlakuan 1,2, dan 3, sedangkan antar ketebalan perlakuan 1, 2, dan 3, tidak ada perbedaan yang signifikan. Secara statistik, penyaringan air menggunakan abu sekam padi mampu menurunkan tingkat kekeruhan secara signifikan bahwa terjadi penurunan rata- rata (mean) nilai kekeruhan dari kontrol terhadap ketebalan saringan pada perlakuan 1, 2, dan 3.

Hasil analisis statistik menunjukkan penyaringan air sungai Martapura menggunakan abu sekam padi dengan perlakuan ketebalan yang bervariasi menghasilkan penurunan nilai parameter kekeruhan secara signifikan.

Percobaan menggunakan saringan abu sekam padi terbukti mampu menurunkan kekeruhan dalam air sungai Martapura secara signifikan, hal ini dapat terlihat rata rata penurunan nilai kekeruhan dibandingkan sebelum dan setelah dilakukan penyaringan. Sebelum dilakukan penyaringan nilai kekeruhan sebesar 35,7 NTU, pada perlakuan satu (menggunakan satu filter) ketebalan filter $13 \mathrm{~cm}$ sebesar 2,97 NTU, perlakuan dua ketebalan filter $26 \mathrm{~cm}$ sebesar 1,17 NTU (menggunakan dua filter), dan perlakuan tiga ketebalan filter $39 \mathrm{~cm}$ (menggunakan tiga filter) sebesar 0,95 NTU, sedangkan 
effektivitas penurunan nilai kekeruhan pada perlakuan satu ketebalan $13 \mathrm{~cm}$ sebesar 91,7 \%, perlakuan dua ketebalan $26 \mathrm{~cm}$ sebesar 96,7\%, sedangkan perlakuan tiga pada ketebalan $39 \mathrm{~cm}$ sebesar $97,3 \%$ telah memenuhi persyaratan kualitas air minum.

Pada penelitian ini ketebalan saringan $13 \mathrm{~cm}$ sudah mampu menurunkan nilai kekeruhan sesuai standar baku mutu air minum yaitu 5 NTU, hal ini disebabkan pada ketebalan $13 \mathrm{~cm}$ susunan partikel abu sekam padi yang terbentuk dalam saringan dengan poripori sudah begitu rapat sehingga partikel tersuspensi pada air sungai Martapura yang tersaring hanya yang berukuran lebih besar dari pori- pori saringan, sedangkan partikel tersuspensi dengan ukuran lebih kecil dari pori- pori saringan akan lolos. Idealnya semakin tebal susunan abu sekam padi maka semakin tinggi efektifitas alat dalam menurunkan kekeruhan karena saringan yang terbentuk semakin kompleks, namun dari segi efesiensi semakin tebal saringan maka semakin sedikit air yang dihasilkan akibat debit air yang semakin kecil.

Kekeruhan pada air sungai Martapura sebesar 35,7 NTU berasal dari lumpur yang masuk kedalam air terdiri dari bahan- bahan tersuspensi yang dibawa oleh aliran sungai dari bagian hulu sungai hingga kebagian hilir. disamping itu juga adanya limbah rumah tangga yang lansung dibuang ke sungai sehingga terjadi proses dekomposisi didalam air. Kekeruhan juga dipengaruhi oleh adanya benda tercampur atau benda koloid di dalam air. Kekeruhan disebabkan oleh bahan-bahan atau partikel tersuspensi yang berkisar dari ukuran kecil koloidal sampai bahan-bahan kasar yang tersuspensi yang berkisar dari ukuran kecil koloidal sampai bahan-bahan yang kasar. Sebagian besar kekeruhan pada air sungai Martapura akibat tingginya jumlah zat padat tersuspensi.

Kekeruhan dapat dihasilkan dari proses fisik mekanis maupun kimiawi seperti sedimentasi dan dekomposisi. Kekeruhan juga membuat perbedaan nyata dari segi estetika maupun dari segi kualitas air itu sendiri. Kekeruhan dalam air bersih didefinisikan sebagai ukuran yang menggunakan efek cahaya sebagai dasar untuk mengukur keadaan air baku dengan skala NTU (nephelometrix turbidity unit) atau JTU (jackson turbidity unit) atau FTU (formazin turbidity unit) Menurut Asdak (2002), kekeruhan menunjukkan nilai kejernihan aliran air atau kekeruhan aliran air yang diakibatkan oleh unsurunsur muatan sedimen, baik yang bersifat mineral atau organik. Kekeruhan dapat dianggap sebagai indikator kemampuan air dalam meloloskan cahaya tersebut kemudian disebarkan atau diserap oleh air tersebut. Semakin kecil nilai kekeruhan suatu perairan, semakin dalam cahaya dapat masuk kedalam badan air dan semakin besar kesempatan bagi vegetasi aquatis untuk melakukan proses fotosintesis maka semakin besar persediaan oksigen yang ada dalam air[7].

Menurut Boyd (1990), kekeruhan disebabkan oleh bahan-bahan atau partikel tersuspensi yang berkisar dari ukuran kecil koloidal sampai bahan-bahan kasar yang tersuspensi yang berkisar dari ukuran kecil koloidal sampai bahan-bahan yang kasar. Kekeruhan dapat dihasilkan dari proses fisik mekanis maupun kimiawi seperti sedimentasi dan dekomposisi ${ }^{[8]}$.

Kekeruhan tidak berdampak langsung terhadap kesehatan tetapi menimbulkan gangguan estetika dalam air bersih maupun air minum, sehingga mengganggu kenyamanan dalam mengkonsumsi air. Di samping itu, kekeruhan menunjukkan adanya tersuspensi dalam air sungai. Oleh sebab 
itu kekeruhan harus dikendalikan agar memenuhi persyaraan air besih menurut Permenkes No. 416 Tahun 1990 dengan peruntukan air sebagai air bersih ${ }^{[9]}$.

Susunan partikel abu sekam padi secara vertikal membentuk saringan dengan pori-pori yang rapat sehingga memiliki kemampuan untuk menyaring partikel yang tersuspensi dalam air. Partikel tersuspensi dengan ukuran yang lebih besar daripada pori-pori saringan akan tertahan di antara butiran-butiran abu sekam, sedangkan yang berukuran kecil kemungkinan lolos bersama partikel air. Mekanisme ini dikenal dengan istilah filtrasi. Menurut Kusnaedi (1998) filtrasi adalah suatu proses pemisahan antara padatan atau koloid dengan cairan melalui media berpori[1].

Dalam hubungannya dengan kebutuhan manusia akan air bersih dan air minum dengan memperhatikan adanya efek gangguan kesehatan yang dapat ditimbulkan karena pemakaian air tersebut, maka ditetapkanlah standar kualitas air bersih dan air minum. Menurut Peraturan Menteri Kesehatan Republik Indonesia

No.416/MENKES/PER/IX/1990 tentang syarat- syarat kualitas air bersih mengatakan bahwa standar persyaratan kualitas air bersih, sedangan untuk kualitas air minum diatur dengan Kepmenkes RI No.492/Menkes/IV/2010 perlu ditetapkan dengan pertimbangan: Bahwa dalam rangka meningkatkan derajat kesehatan masyarakat, perlu dilakukan pengawasan air secara intensif dan terus menerus. Kualitas air yang digunakan masyarakat harus memenuhi syarat kesehatan agar terhindar dari gangguan kesehatan.

Dari uraian di atas jelas adanya kaitan yang erat antara usaha penempatan standar kualitas air dengan pencegahan resiko terhadap kesehatan manusia yang dapat ditimbulkan oleh pemakaian air tersebut. Standar kualitas air yang ditetapkan oleh Dep. Kes. R.I. sebagaimana yang ditetapkan oleh U.S. public Health Service, mencakup empat pokok persyaratan, yakni; fisik, kimia, bakteriologis, dan radioaktif.

Sesuai dengan dasar petimbangan penetapan standard kualitas air bersih tersebut di atas, usaha pengolahan air dengan menggunakan saringan abu sekam padi perlu dilakukan terhadap air sungai Martapura yang digunakan oleh masyarakat disekitar bantaran sungai sebagai air besih berpedoman pada standar kualitas tersebut, terutama di dalam melakukan penilaian terhadap air hasil saringan yang dihasilkan.

\section{KESIMPULAN DAN SARAN}

Penyaringan air sungai Martapura dengan abu sekam padi penurunan ratarata nilai Kekeruhan tanpa perlakuan sebesar 35,7 NTU, Pada perlakuan satu sebesar 2,97 NTU, perlakuan dua sebesar 1,17 NTU, sedangkan pada perlakuan tiga sebesar 0,95 NTU, ada perbedaan tingkat ketebalan saringan abu sekam padi pada masing-masing perlakuan perlakuan satu, dua, dan tiga terhadap perlakuan kontrol dalam menurunkan nilai kekeruhan pada air sungai Martapura dan prosentasi penurunan nilai kekeruhan menggunakan media filtrasi abu sekam padi pada tingkat ketebalan saringan perlakuan satu sebesar $91,7 \%$, perlakuan dua sebesar $96,7 \%$, dan perlakuan tiga sebesar $97,3 \%$.

\section{KEPUSTAKAAN}

1. Kusnaedi (1998) Mengolah Air Gambut dan Air Kotor Untuk Air Minum. Penebar Swadaya. Jakarta.

2. Khiatuddin Maulida (2006) Melestarikan Sumber Daya Air dengan Teknologi Rawa Buatan. Gadjah Mada University Press. Yogyakarta.

3. Olvira, S, A. (2016). Perbadaan Kemampuan Filtrasi Menggunakan Media Pasir Taluk, Pasar Martapura, dan Pasir Pantai untuk menurunkan 
Tingkat Kekeruhan Air Sungai Martapura.

4. Zubaidah, T., M.irfa'i, \& Setiadi, G. (2006). Desain Alat Floating Water Intake Treatment Untuk Menurunkan Tingkat Kekeruhan Air Sungai Martapura. Jurnal Kesehatan Lingkungan, 13-21.

5. Syaifudinnor, A. (2006). Desain Alat Pengolahan Air Sungai Martapura Dengan Filtrasi.

6. Sutrisno Totok dan Eni Suciastuti (2005) Teknologi Penyediaan Air Bersih. PT. Rineka Cipta. Jakarta.
7. Asdak C. (2002) Hidrologi dan Pengelolaan Daerah Aliran Sungai. Gadjah Mada University Press. Yogyakarta.

8. Boyd CF (1990) Water Quality in Pond for Aquaculture. Departemen of Fisheries an Applied Aquqcultures. Birmingham Publishing Alabama. Alabama.

9. Depkes Rl (1990) Peraturan Menteri Kesehatan RI Nomor 416/Menkes/Per/IX/1990 Tentang Syarat-syarat dan Pengawasan Kualitas Air. Jakarta. 
